\title{
General Interlibrary Loan Code 1952
}

The General Interlibrary Loan Code 1952 was accepted on July 4, 1952, by the Council of the American Library Association as replacement for the ALA Interlibrary Loan Code I940, of which it is an enlargement and revision. It has also been approved by the executive bodies or membership of the American Association of Law Libraries, American Theological Library Association, Catholic Library Association, the ALA Public Libraries Division, the Special Libraries Association (in principle), and of course, the Association of College and Reference Libraries.

This 1952 Code was prepared by the Committee on Interlibrary Loans of the ACRL. The final draft represents two years of committee work and the suggestions of more than 75 librarians representing all types of libraries. This basic code reaffirms accepted policies and establishes standard procedures to cut costs and control the greatly increased volume of loans. With this code as a basis special types of libraries (such as music, medical, or state libraries) may easily develop supplements to cover their unique needs.

The code does not answer all questions pertaining to interlibrary loans, nor can it be all things to all libraries, but it can be used in the following ways: to provide a manual of generally accepted procedures for librarians without previous training or experience in handling interlibrary loans; to correct abuses of the interlibrary loan privilege and to bear witness that the service is a courtesy and not a right; and, finally, to effect a more efficient handling of interlibrary loan requests so as to relieve a measure of the present strain on the large research libraries which bear the principal burden of the loans between libraries.

Members of the ACRL Committee on Interlibrary Loans are: Mollie Hollreigh; Louise M. Milligan; Dorothy S. Scherer; Bernice S. Smith; Margaret D. Uridge; and William A. Kozumplik, Chairman.

Reprints of the General Interlibrary Loan Code 1952 may be obtained for a nominal sum from Gaylord Brothers, Syracuse, New York.

"Continued disregard by a borrowing library of the provisions of this Code is sufficient reason for another library to decline to lend to said library. . . Interlibrary loan service is a courtesy and a privilege, not $a$ right, and is dependent upon the cooperation of many libraries."

\section{Introduction}

I. Interlibrary loans are transactions in which material is lent by one library to another library for the use of an individual borrower. Interlibrary loan service supplements a library's resources by making available, through direct loans for a short period of time, materials located in other libraries and not owned by the borrowing library.

2. The volume of interlibrary loans makes it desirable to formulate basic policies regulating this service and to recommend the national adoption of standard forms and uniform operating practices in the interest of maximum reciprocal effectiveness, efficiency, and economy. To this end the General Interlibrary Loan Code, consisting of policies and operational procedures, is set forth.

3. This General Code does not deny the formulation of special codes, which would widen and extend the purpose and scope herein stated. Such codes are generally mutual assistance agreements, based on the national code, written for specified libraries, e.g., the members of a regional union catalog or bibliographic center, and for library systems of a similar type or of a geographic area, such as state library service (sometimes called "extension service"), school systems, large public library branch systems, e'c.

\section{Definition of Pumpose}

T) e purpnse of interlibrary loans is to make a atiable for researcl, and for serious study li ary materiais not . given library, with due provisions made by the lending library for the rigi.ts of its primary clientele.

\section{Responsibility}

1. Inter library loan service is a courtesy and a privilege, not a right, and is dependent upon the cooperation of many libraries. Because of the cost of the service and the conflict in demands for certain classes of material, the interlibrary loan service should be restricted (especially when borrowing from large research libraries) to requests that cannot be filied by any other means.

2. In the interest of furthering cooperative 
research both the borrowing library and the lending library are responsible for understanding and abiding by the purpose and limitations of such loans; it is especially desirable that the lending library interpret as generously as possible its own lending policies.

3. As applied to research for advanced degrees, it is assumed that the candidates in any institution will choose dissertation topics according to the resources at hand and not those which will involve attempting to borrow a large part of the necessary library resources from other libraries.

4. It is assumed that the borrowing library will carefully screen all applications for loans and that it will reject those which do not conform to the Code.

\section{Conditions of Loans}

1. The safety of borrowed materials is the responsibility of the borrowing library from the date of their arrival in that library to the date of their receipt back by the lending library.

2. In the case of loss or damage the borrowing library is obligated to meet the cost of repair, rebinding, or replacement (including processing costs), or to supply a replacement copy, whichever is preferred by the lending library.

3. The borrowing library is bound by any conditions or limitations of use imposed by the lending library. If no specific conditions have been made, the borrowing library will safeguard borrowed materials as carefully as it would its own.

4. It is recommended that any limitations on use (such as "For use in library building only") be based on the physical condition or the bibliographic character (e.g., rarity, fragility, uniqueness, etc.) of particular items rather than blanket restrictions on all materials lent.

5. Photographic reproductions should not be made of theses, manuscripts, or other unique materials on loan without first receiving permission from the library owning the original.

6. Special conditions on the use of unpublished theses may be imposed by the lending library. These may include restrictions to use within the library building; permission required from the author for the loan or reproduction of the thesis; signing by the individual borrower of a "use sheet" in front of thesis.

\section{Scope}

I. Almost any material possessed by a library, unless it has been acquired on terms which entirely preclude its loan or duplication, may on occasion be lent to or photographed for another library. The lender alone must decide in each case whether a particular loan or photographic copy should, or should not, be made.

2. However, because of the purpose of interlibrary loans, libraries should not request, especially of research libraries, the following types of materials (unless asking under a special cooperative agreement): Current fiction; current issues of periodicals (some libraries may be willing to lend current issues of foreign or little used periodicals); inexpensive items currently purchasable in this country; books for class use; a high percentage of the books basic for a thesis being written for the borrowing institution; current books for which there is anticipated a recurring demand in the borrowing library.

3. Moreover, libraries ought not request, especially of research libraries, excepting under unusual and explained circumstances the following types of materials: extremely rare books; a very large number of titles at one time for one applicant; music to be used in public performance; works difficult and expensive to pack, e.g., newspapers.

4. Furthermore, libraries should be prepared to have their requests unfilled if the material requested is considered by the owning library to be too rare, fragile, irreplaceable (manuscript or other unique item) or if it is of a collection which cannot leave the premises; is in great demand, either actual or immediately anticipated; or is a microfilm or other photographic reproduction for which the original material or another film copy is not easily available for replacement copying. (Cf. Appendix V: Policy on the Interlibrary Lending of Microfilm.)

\section{Expenses}

I. Payment of transportation costs both ways, including insurance, is to be met by the borrowing library except where agreements to the contrary exist.

2. It may be necessary for some libraries to add a flat service charge per transaction for professional and clerical services rendered.

3. The borrowing library may require, de- 
pending upon its policy, total, partial, or no reimbursement of expenses from the applicant for whom the transaction was negotiated.

4. Payment of costs is normally made at the conclusion of each transaction by the borrowing library enclosing the sum in stamps with the notice of return shipment (not with the material itself) or periodically on receipt of a bill from the lending library.

Note: In order to avoid the use by some libraries (including many government libraries) of expensive shipment by expresscollect, the borrowing library may arrange to send with its requests the estimated postage for book-rate shipment.

5. In order to keep expenses as low as possible, especially clerical costs, it is recommended that standard labor-saving devices (cf. Appendixes I and II) and uniform procedures especially designed for interlibrary loans be utilized.

\section{Placement of Requests}

I. Libraries should apply first to the nearest institution known or expected to possess the desired material. Special care must be taken, however, to avoid asking the larger libraries to support an undue proportion of the interlibrary loans. Unless mutual agreements are operative, avoid concentrating requests upon a few libraries.

2. When it is not known where the desired material is, or might be located, a regional union catalog or the National Union Catalog at the Library of Congress may be consulted. (Cf. Appendix IV for list of addresses.)

\section{Information Required on Requests}

I. Materials requested must be described completely and accurately, following accepted bibliographic practice (see VIII.3 below).

2. Items requested should be verified and sources of verification given. (Cf. Appendix III for standard abbreviations of sources of verification.) When verification is impossible, because of lack of bibliographic tools, the statement "Cannot verify" should be made and the original source of reference be cited, including page reference. If this provision is disregarded, and the bibliographic data appear to be incorrect, the request may be returned unfilled. is:

3. Specific information required for requests a. BOOKS or pamphlets:

I. Full author entry, corporate or personal; when personal, supply full names, or at least the correct surname and initials of forenames if full names are not ascertainable.

2. Title, exact and full enough for positive identification.

3. Edition, when a particular one is sought. Specify "Any edition" if such is satisfactory.

4. Imprint, including place of publication, publisher (if known) and date.

5. Volume number if part of a set; give title of set if different from individual title.

6. If part of a series, give title of the seeries and the serial number of the item.

b. SERIALS:

I. Exact title of the serial, complete enough for positive identification.

2. Volume number.

3. Date of volume; if very recent volume or if issues are separately paged, give also the number and/or date of the issue wanted.

4. Inclusive pagination of article desired, if this information is available.

5. Author and title of the article, or subject if the title is not known.

Note: Occasionally special and government libraries will withhold this information in order to protect their organization's research interests.

4. For foreign language material, author and title, and/or serial title, must be in the language of the version desired, not in translation. In the case of non-Roman alphabetic languages, this information should be transliterated. For Oriental languages, and other languages admitting of several transliterations, the transliteration should be accompanied by slips giving the author and title in the original script, supplied by the applicant for the loan.

5. If the applicant's name, status (occupation or other identifying description), and purpose are given on the request, the loan frequently may be obtained when otherwise it might be refused. This information may be required by some lending libraries.

6 . If there is a date by which the material must be received to be useful, this should be indicated on the request. 
7. It is recommended that the borrowing library in initiating requests use standard multiple-part carboned unit-request forms, utilizing window envelopes, as approved in principle by the ACRL. Their use is described below. (Cf. Appendix II for further description.)

a. If forms cannot be used, the same principles should be followed in request correspondence, particularly in respect to giving only a single title per letter sheet.

b. It is understood that use of the multiplepart unit-request form described below does not necessarily apply to loans within a cooperative agreement system which has its own special forms and procedures. It is recommended, however, that libraries within such a system abide by the provisions below when making requests of libraries outside their "system."

c. Use of the multiple-part unit-request form:

I. Each request form should contain only one book-title or one volume of a serial.

2. The name and address of both the borrowing and lending library should be on each unit-request.

3. The first 3 parts of the request form are to be sent to the lending library as the initial request.

4. Several unit-request forms may be placed in one envelope (window envelopes are recommended). However, do not add to a unit-request form any information or question regarding a different request.

5. Self-addressed gummed standard interlibrary loan shipping labels (cf. Appendix I) should be enclosed for each unit-request. (Enclose 2 for each request to be shipped by express.)

6. It is an added courtesy to enclose a stamped self-addressed, or window envelope for the lending library to use in answer to requests.

8. All correspondence and shipments should have "Interlibrary Loan" conspicuously placed on the envelope and shipping label. To save on clerical costs it is recommended that, in the use of forms and shipping labels, the librarian handling interlibrary loans be addressed by title: Interlibrary Loan Librarian, rather than by name.

\section{Photographic Substitution}

I. Time may be saved in filling the reader's request if, in the application for a loan, willingness is indicated to purchase a photographic reproduction as a satisfactory substitute should the original material be unavailable for interlibrary loan. This is especially applicable to periodical and newspaper articles and to typescript theses.

2. The type of photographic duplication (as a substitute) that is acceptable (e.g., photostat; microfilm-negative or positive; record print; etc.) and the maximum price the borrowing library is willing to pay can appropriately be indicated on the original request. If preferred, the lending library may be asked to quote the estimated cost of such a substitution before filling the order.

3. Photographic duplication in lieu of interlibrary loan may be complicated by interpretations of copyright restrictions, particularly in regard to photographing whole issues of periodicals or books with current copyrights, or in making multiple copies of a publication.*

4. Any request, therefore, that indicates acceptability of a photographic substitution, under the conditions described above, should be accompanied by a statement with the signature of the applicant attesting to his responsibility for observing copyright provisions in his use of the photographic copy.*

5. Requests indicating acceptability of photagraphic substitute in lieu of interlibrary loan that comply with the above provisions are to be considered bona fide orders for copying services. The lending library, if equipped to do so, may fill such orders with no further correspondence or delay.

\section{Shipment of Loans}

I. In the shipment of materials on interlibrary loan use the least expensive method of transportation. Keep in mind the reliability and speed of the method, and the physical and bibliographic condition of the material being sent.

2. There is no commitment on the part of the borrowing library, unless otherwise di-

* These statements on photographic substitution are based on the "Gentlemen's Agreement" written in 1935 by the National Association of Book Publishers (reaffirmed in 1938 by its successor the Book Publishers Bureau) and the Joint Committee on Materials for Re. search (representing the libraries). For the text of this agreement see the Journal of Documentary Reproduction, 2:29-36, March 1939. 
rected, to use the same method of shipment adopted by the lending library if it can return the item just as reliably, safely, and quickly at less cost. It is emphasized, however, that U. S. Postal Regulations require that typescript or manuscript materials be sent first class mail, or they may be sent by express.

Note: Shipping by express by the lending library merely as a convenience in collecting transportation costs is not justified due to its much higher costs.

3. Proper attention should be given to the preparation of materials for shipment to insure their safe and unharmed arrival at the intended destination. This involves heavy protective covering and proper addressing.

a. Books should be protected by the use of corrugated paper or cardboard, covering all edges and corners especially well, plus heavy wrapping paper. Prefabricated shipping bags, if used judiciously (keeping in mind weight of the book, shipping distance, and the routes or postal offices known to be excessively hard on shipments) may be considered for use as a labor saving device.

b. Pamphlets or works of a similar nature may be safely shipped in cardboard reinforced strong manila envelopes or in prefabricated shipping bags.

c. Microfilm reels should be kept in their original cardboard containers and sent in special shipping boxes, or wrapped as carefully as books. When microfilms are returned they should be on the reels originally sent, as well as in the original cardboard containers (which are in effect the covers of a book) containing the title and call-number.

d. The borrowing library should give at least the same care in preparing materials for return shipment as was given by the lending library in preparing the original shipment.

\section{Insurance}

I. It is recommended that especially valuable shipments be insured, the lending library determining the amount of insurance. When shipping to another country, e.g., Canada, shipping experience recommends registering (for quick passage through customs) rather than insuring.

2. When returning materials the borrowing library should insure and/or register the shipment for at least the amount stipulated by the lending library.

3. Where the volume of transactions warrants, blanket parcel post insurance provided by private insurance companies might well be considered.

\section{Duration of Loan}

I. The duration of loan is normally calculated to mean the period of time the item is to be in the borrowing library, disregarding the time spent in transit.

2. The loan period is often limited to two weeks for books and one week for unbound periodical issues. However, some libraries grant longer initial loan periods as a matter of policy or under very special circumstances.

\section{Renewal}

1. Renewal requests should not be encouraged. In any case a second renewal should not be asked for without a specific explanation. It should be remembered that the borrowed material was originally acquired for the use of the owning library's clientele, and should be available on its shelves.

2. The renewal request should reach the lending library on or before the date due.

3. The lending library should answer the borrowing library's renewal request promptly. If renewed, the lending library indicates the new due date or the renewal period granted.

\section{Recall}

Material on loan is subject to recall at any time at the discretion of the lending library. The borrowing library should comply promptly.

\section{Notification and Acknowledgment}

I. If the lending library cannot send the material requested, it is expected that it notify the requesting library promptly, giving the reason why the material is unavailable.

2. When the lending library fills a request, a notification of shipment should be sent separately from the material itself (to alert the receiving library to probable date of arrival). On this notice of shipment the lending library gives the following: date and method of shipment, including the amount of insurance cover- 
age (if any); date material is due or loan period; charges to be refunded, if any.

Note: To expedite return shipments the lending library is wise to enclose with the shipment-notification a self-addressed gummed shipping label (or two, if shipment is to be by express).

3. In return shipments the borrowing library sends, separately from the material itself, notification giving the date and method of shipment, including insurance coverage (if any).

4. Acknowledgments: Experience recommends that except for extremely valuable shipments, or those from a foreign country, no acknowledgment of receipt is necessary.

However, if there is undue delay in receipt of the item (date of shipment is stated in the notification of shipment) the receiving library (whether borrowing or lending) has the responsibility of notifying the sending library so that a search may be initiated promptly. In such a case, notification to the shipping library may be made, when using the multiple-part forms, on the verso of the "interim report" sheet or "return notice" sheet; or otherwise by post card or letter using abbreviated bibliographic description.

\section{Violations of the Code}

Continued disregard by a borrowing library of the provisions of this Code is sufficient reason for another library to decline to lend to said library.

\section{APPENDIX I}

\section{Standard Interlibrary Loan Shipping Label Specifications:}

Size: $3^{\prime \prime} \times 5^{\prime \prime}$, for easy filing in standard library equipment.

Spacing: Address of receiving library to occupy center and major portion of label. Address of sending library to be at left edge, near top, preferably printed at right angles to that of receiving library and rest of printing on the label.

Postal Regulations: Words "Interlibrary Loan" and "Books" to be printed clearly at top. "May be opened for postal inspection" and "Return postage guaranteed" to be printed at bottom of label, preferably in type differing from rest of printing on label.
"Mailed under Sec. 34.83 P.L. \& R." to be at top of label, in distinctive type, providing the library is entitled to mail under its provisions. This postal regulation is for nonprofit, public libraries so cannot be used by commercial, special libraries.

Instructions: Methods of shipment, including insurance valuation note, to be pre-printed, for quick checking, at bottom of label.

Color: Light enough to show typing clearly. Large libraries may wish to have a distinctive color to aid in prompt sorting and distributing of interlibrary loans.

Self-addressed Labels: A library should send the library at the other end of the transaction a gummed, self-addressed, pre-printed or pre-typed shipping label when expecting an interlibrary loan volume to be shipped to it, either on loan or as return of a loan.

\section{ApPendix II}

Standard Interlibrary Loan Request Form (Accepted in Principle, July 195 I, by the ACRL Board of Directors)

USE OF THE FOUR-PART, CARBON INTERLEAVED, $5^{\prime \prime} \times 8^{\prime \prime}$ UNITREQUEST FORM, Using WindowEnvelope (See next page for Sample):

Part A (white): "Request," sent with Parts $B$ and $C$ as initial request; it becomes the lending library's final record.

Part B (yellow): "Report," used by the "lending library to answer the request; it becomes the borrowing library's final record.

Part $C$ (pink): "Interim Report," used by the lending library when necessary for delayin-shipment reports, such as: "In use, hold placed (will send later)."

If it is not so used, Part $C$ is returned to the borrowing library either with Part $B$ or with the material shipped.

It then becomes the borrowing library's "Renewal Request," when renewal is necessary.

It is Part $C$ which acts as a "flyer" between the two libraries involved. It may be discarded at the transaction's termination.

Part D (goldenrod): "Notice of Return," retained by the borrowing library until the material borrowed is ready fot réturn. Filled in with method and date of shipment, it is sent separately to the lending library as return notification. 


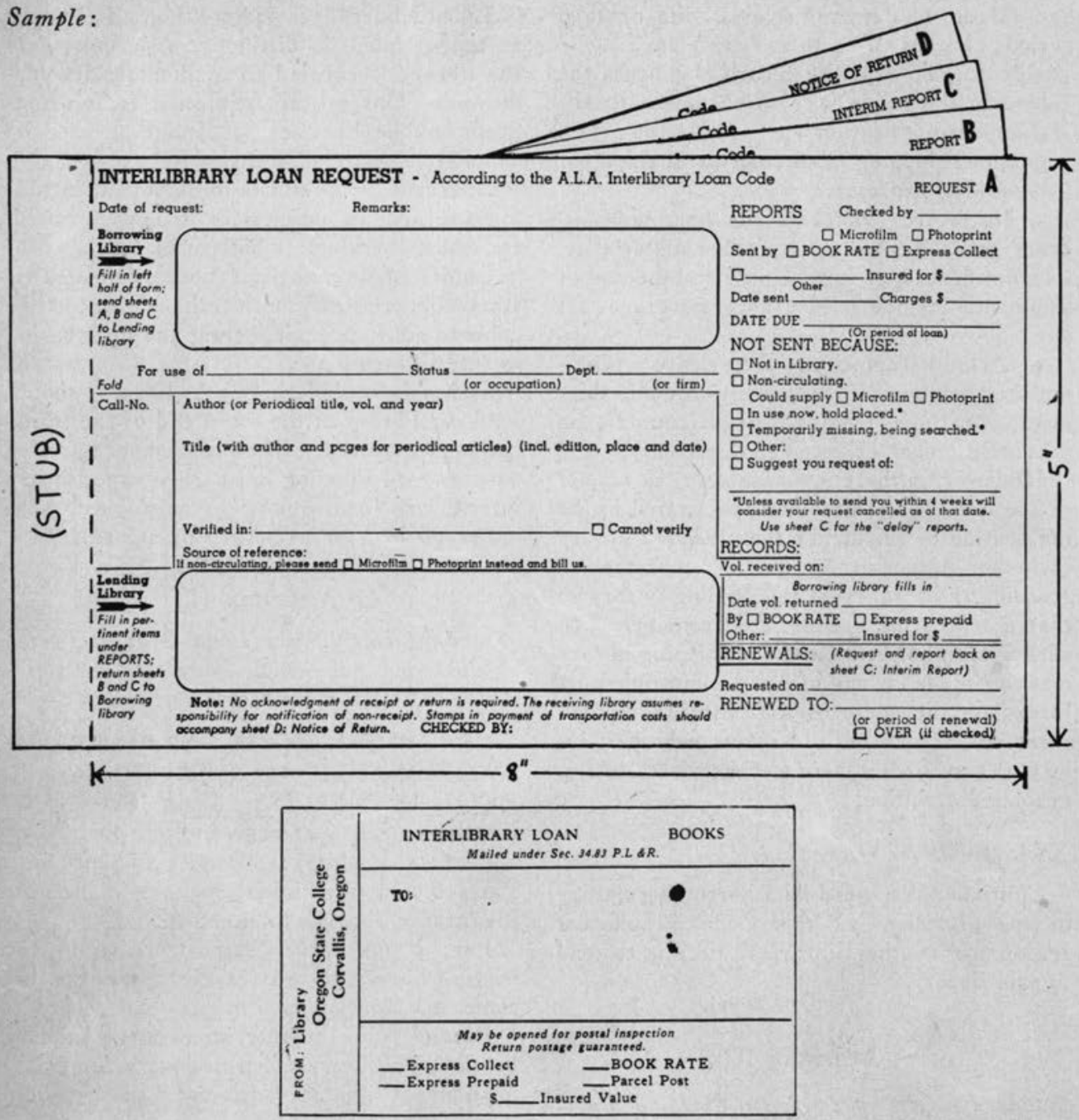

For rare materials, Part $D$ could be used for acknowledgment of receipt.

It may be discarded at the end of the transaction.

\section{Procedure:}

I. The borrowing library types the required information on the left two-thirds of the fourpart form. Additional information or special considerations may be placed under "Remarks" or on the reverse of the form; in the latter case, check "Over," on the bottom. The librarian initiating the transaction should sign or initial the request next to "Checked By."
2. The borrowing library sends Parts $A$, $B, C$ in a window envelope to the lending library; it also encloses a self-addressed gummed shipping label. Part $D$ is retained as the initial record of its request. "

Note: Several unit-requests, fully filled in, may be included in one envelope.

3. The lending library fills in and checks on all three parts, the appropriate information under the form's "Reports" section; it retains Part $A$ and returns Parts $B$ and $C$ to the borrowing library.

If the material is being shipped, Part $B$, together with a self-addressed gummed shipping label, is sent separately from the ma- 
terial, thus alerting the borrowing library of its imminent arrival.

Part $C$ may be sent with Part $B$ or may be used as a packing slip for the shipment.

Note: Part $C$ is designed to be sent ahead of Part $B$ if there is to be a delay in shipping the requested material.

4. The borrowing library uses Part $C$ to request a renewal, if necessary. The lending library returns Part $C$ with new due date or renewal refusal.

5. The borrowing library uses $\operatorname{Part} D$ as. notification of return shipment of the material, thus making Part $B$ its final record of the transaction.

\section{APPENDIX III}

\section{Standard Abbreviations of}

\section{Sources of Verification}

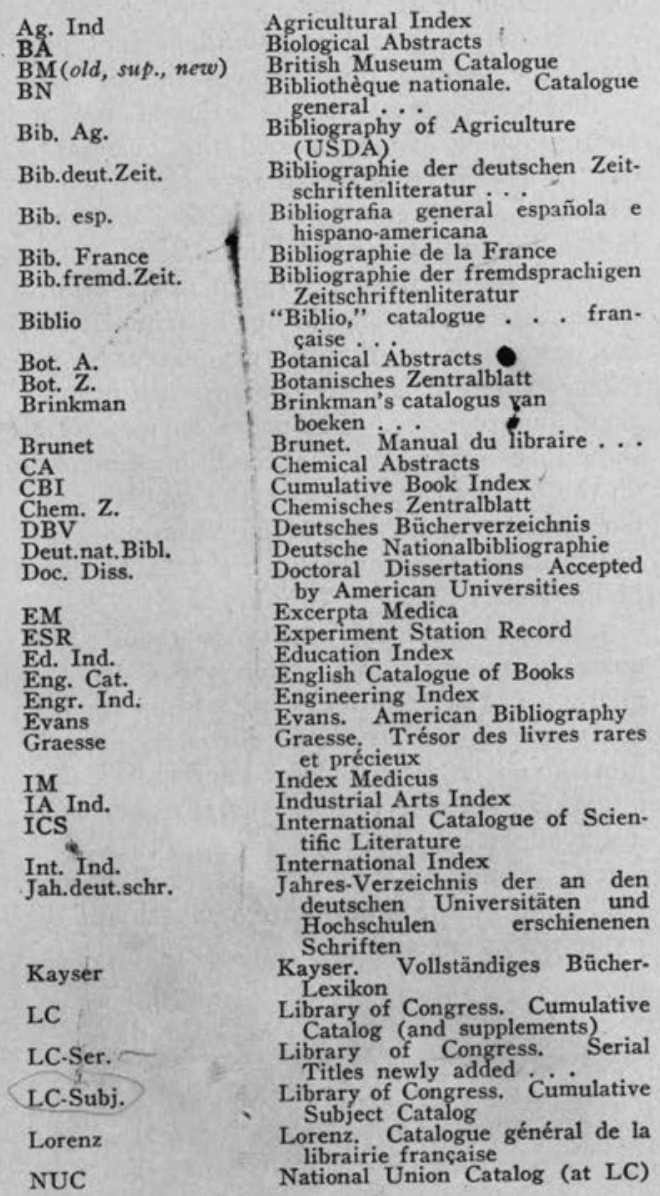

PTLA

Paglianin!

Palau

Psych. A.

RG

RSL-Sci.

SA-A

SA-B

SPFG

STC.P

STC.W

Sabin

ULN

ULS

U.S. Cat.

U.S. SG

WLSP

Watt

ZR
Public Affairs Information Service

Paglianini. Catalogo generale della liberia italiana

Palau y Dulcet. Manual del librero hispano-americano

Psychological Abstracts

Readers' Guide to Periodical Literature

Royal Society of London. Cata. logue of the Periodical Publications in the Library

cations in the Library
Royal Society of London. Catalogue of Scientific Papers.

Science Abstracts Sect. A. Physics Abstracts

Science Abstracts Sect. B. Electrical Engineering Abstracts

List of the Serial Publications of Foreign Governments

Pollard. A Short-title Catalogue Wing. A Short-title Catalogue

Sabin. Dictionary of Books Relating to America

Union List of Newspapers

Union List of Serials

United States Catalog (and sup. plements)

U. S. Surgeon General. Index. Catalogue of the Library

World List of Scientific Peri. odicals

Watt. Bibliotheca Britannica

Zoological Record

\section{Appendix IV}

\section{Bibliographic Centers and Selected Union Catalogs}

National Union Catalog, Library of Congress, Washington 25, D.C.

Canadian Bibliographic Centre, Public Archives of Canada, Ottawa, Ontario.

Bibliographic Center for Research, Rocky Mountain Region, Public Library, Denver 2.

Pacific Northwest Bibliographic Center, Univ. of Washington Library, Seattle 5.

Philadelphia Bibliographical Center and Union Library Catalogue, Univ. of Pennsylvania, 107 Engineering Building, Philadelphia 4.

Cleveland Regional Union Catalog, Thwing Hall, Western Reserve Univ., Cleveland 6.

California State Union Catalog, State Library, Sacramento 9.

Nebraska Union Catalogue, Nebraska State Library Commission, State House, Lincoln 9.

Union Catalog of Nonfiction in New Hampshire Libraries, State Library, Concord.

Union Catalog of Material in Libraries and in Private Collections in New Jersey, New Jersey Public Library Commission, State House Annex, Trenton 7. 
Ohıo Union Catalog, Ohio State Library, State Office Building, Columbus 15.

Vermont State-Wide Union Library Catalog, Vermont Free Public Library Commission, Montpelier.

Duke and State Union Catalog, Univ. of North Carolina, Chapel Hill.

Austria. Oesterreichische Nationalbibliothek. Vỉenna I, Josefsplatz.

Belgium. Bibliothèque Royale, Place de Musée, Brussels.

Denmark. Statens Bibliotekstilsyn. Odensegade I4, Copenhagen $\emptyset$.

Finland. Helsingen Yliopiston Kirjasto. (Helsinki University Library) Helsinki, Unioninkatu 36.

France. Bibliothèque Nationale, 58 rue de Richelieu, Paris II.

Germany. Öffentliche Wissenschaftliche Bibliothek (formerly Preussische Staatsbibliothek) N. W. 7, Unter den Linden 8 , Berlin.

Universitäts- und Stadtbibliothek, Cologne. Great Britain. National Central Library, Malet Place, London, W.C. I. England. Italy. Biblioteca Nazionale Centrale Vittorio Emanuele. Via del Collegio Romano 27. Rome.

Centro Nazionale per il Catalogo Unico delle Biblioteche Italliane e per le Informazione Bibliografiche. Rome. (Being established.)

The Netherlands. Koninklijke Bibliotheek.

Lange Voorhout 34. The Hague.

Norway. Universitets Bibliotek, Oslo.

Spain. Biblioteca Nacional. Av. de Calvo Sotelo 20, Madrid.

Sweden. Kungl. Biblioteket. Stockholm 5, Humlegarden.

Switzerland. Bibliothèque Nationale SuisseSchweizerische Landesbibliothek. 15 Hallwylstrasse, Berne.

Zentralbibliothek Zürich. Zähingerplatz 6, Zürich I.
Appendix V

Policy on the Interlibrary Lending of Microfilm

(Statement Accepted by the ARL as a Committee Report, January 26, 1952, at Iowa City)

The Committee on Interlibrary Lending of Microfilm favors a liberal policy of microfilm lending. The principal provisions of such a policy are set forth below. It should be borne in mind that any one provision listed below is subject to the limitations implied in the other provisions.

I. The conditions of loan set forth in the 1952 revision of the ALA Interlibrary Loan Code should apply to the interlibrary lending of microfilm. Specific reference is made in the Code to the purpose, responsibilities, expenses, and duration of interlibrary loans.

2. Positive microfilm should be lent freely and without restriction.

3. Negative microfilm should be lent provided the lending library owns the original, or has easy access to the original for rephotographing, and provided the original is not so fragile that re-photographing would damage it. Extreme care should be exercised in handling negative microfilm.

4. Microfilm of manuscript material owned by another library should not be lent without the permission of that library except in instances where it is quite obvious such permission is unnecessary. The use of such material should be subject to the conditions imposed on the borrowing library by the report of the Committee on the Use of Manuscripts (Appendix B, p.32, Minutes of the 37th Meeting of the ARL, Chicago, July 6-7, 1951).

5. The requesting library is required to name in the first application for a loan of microfilm the type of microfilm reading equipment it has available for use. Microfilm should be restricted for use in the building where suitable equipment and supervision are available for its use.

6. The minimum unit of loan will be one reel. Not more than four reels should be requested at one time. 